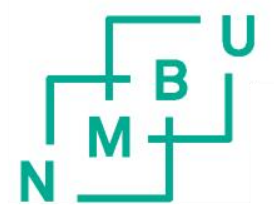

Norwegian University of Life Sciences

School of Economics and Business

No sense of ownership in weak participation: a forest conservation experiment in Tanzania

Øyvind Nystad Handberg 


\title{
No sense of ownership in weak participation: a forest conservation experiment in Tanzania
}

\author{
ØYVIND NYSTAD HANDBERG* \\ School of Economics and Business, \\ Norwegian University of Life Sciences (NMBU), 1432 Ås, Norway \\ oyvind.handberg@nmbu.no
}

\begin{abstract}
Sense of ownership is often advocated as an argument for local participation within the epistemic development and nature conservation communities. Stakeholder participation in initiating, designing or implementing institutions is claimed to establish a sense of ownership among the stakeholders and subsequently improve the intended outcomes of the given institution. Theoretical and empirical justifications of the hypothesis remain scarce. A better understanding of the effects of local participation can motivate more extensive and stronger participation of local stakeholders and improve institutional performance. This paper applies theories from psychology and behavioral economics to better understand sense of ownership. The empirical investigation is a framed field experiment, in the context of tropical forest conservation and payments for environmental services in Tanzania. The results lend little support to the hypothesis in this context. The participation treatment in the experiment is weak, and a possible explanation is that sense of ownership is sensitive to the form of participation.
\end{abstract}

Keywords: participation; sense of ownership; forestry; Tanzania; framed field experiment

* I appreciate financial support from the Center for International Forestry Research (CIFOR) and from the Climate Change Impacts, Adaptation and Mitigation (CCIAM) programme, both funded by the Norwegian Agency for Development Cooperation (Norad). I am grateful for valuable comments by Frode Alfnes, Arild Angelsen, Ann-Kathrin Koessler, Nina Bruvik Westberg and seminar participants at Nordev 15. 


\section{Introduction}

A common argument for participation of local stakeholders within the epistemic development and nature conservation communities is that participation directly improves institutions' ability to deliver effective, efficient or equitable outcomes. 1 Dubbed "sense of ownership," the argument hypothesizes that local stakeholders sense ownership of institutions they are involved in initiating, designing and/or implementing. This sense of ownership subsequently increases stakeholder support and thus institutional performance. The argument is found both among project proponents ${ }^{2}$ and in the academic literature (e.g., Lachapelle, 2008; Reed, 2008; Marks and Davis, 2012). Schultz et al. (2011, p. 662) summarize the hypothesis as "people are more likely to support and implement decisions they have participated in making", and Buchy and Hoverman (2000, p. 19) argue that "people, feeling a sense of ownership, will be more compliant to bear the costs." A Google Scholar search reveals 162 articles in ten top development journals mentioning "sense of ownership" in the period 1990-2016. ${ }^{3}$

Despite its popularity, the hypothesis lacks a precise definition. Details remain fuzzy on how participation induces sense of ownership and how it in turn improves institutional performance, controlling for other positive aspects of participation, such as access to local knowledge. One reason is inadequate theoretical tools. "Sense" implies a psychological mechanism, which is rarely explored in the relevant literature. Another reason is challenges in empirically identifying sense of ownership effects. Participation and sense of ownership as elusive concepts makes comparative studies difficult, and persistent biases in observations makes more quantitative investigations difficult. Several scholars note that research assessing the effects of stakeholder participation on institution performance is scarce (Agrawal, 2007; Reed, 2008; Schultz et al., 2011; Marks and Davis, 2012; Mansuri and Rao, 2013b).

Viewing participation as a means, understanding sense of ownership can help initiate, design and implement more efficient, effective and equitable institutions. Viewing participation as an end, finding support for the hypothesis can motivate more and stronger participatory approaches among policy makers.

This paper applies psychology and behavioral economics for a theoretical understanding of sense of ownership, and proposes three possible drivers: biased information processing, associative self-anchoring and cognitive dissonance (Section 3). Economic experiments can help improve our empirical understanding by testing the drivers and controlling for possible confounding factors. Since sense of ownership may be context specific, a framed field experiment tests one specific form of participation in the relevant context of forest conservation in Tanzania (Section 4). The results (Section 5) are discussed in light of participation in development and nature conservation institutions (Section 6), before the conclusion (Section 7). To explore the participation-sense of ownership link, the following section presents a typology of participation.

\section{Participation}

\subsection{Definitions and classifications}

Over the last 40 years, participation has become a core element in the implementation of development and nature conservation institutions in developing countries (Cohen and Uphoff, 1980; Cornwall, 2008; Lie, 2015). Major actors emphasize local participation and partnerships as important factors in their work. For instance, the World Bank spent an estimated USD 85 billion on local participatory projects during the last decade alone (Mansuri and Rao, 2013b).

Despite the long focus on and the positive aspects of participatory approaches, empirical investigations often find implementations to be questionable. In some cases "participation" is more a buzzword in project

\footnotetext{
1 The paper uses the term institution in the understanding of North (1990) as rules that define and/or constrain human interaction. Section 4 presents the institution for empirical investigation.

2 For instance, "[...] broad ownership of a decision makes it more likely that implementation will be supported by a range of stakeholders" (Richards et al., 2004, p. 11); "[c]reating a sense of ownership is essential to building and sustaining productive TB [Tuberculosis] partnerships" (CDC, 2007); "Ownership is an inherently appealing concept. In plain language, people should be involved in determining their own destiny, and if they are, they are more likely to support management efforts designed to move in this direction" (Manning and Ginger, 2007, p. 190); "[p]romoting participation helps build ownerhsip [sic] and enhances transparency and accountability, and in doing so enhances effectiveness of development projects and policies" (World Bank, 2015).

3 World Development (44); Journal of International Development (20); Third World Quarterly (18); European Journal of Development Research (15); Journal of Development Studies (15); Development and Change (13); Development Policy Review (11); Sustainable Development (7); Environment and Development Economics (6); Oxford Development Studies (4) [August 8, 2016].
} 
documents than reality (Baland and Platteau, 1996; Cornwall and Brock, 2005; Alejandro Leal, 2007; Reed, 2008; Ribot et al., 2010; Green and Lund, 2015; Lie, 2015). Another reason for varying practice is that "participation" is subject to a range of definitions, depending on context and objective (Lawrence, 2006; Cornwall, 2008).

This paper views participation as the process where stakeholders make choices that determine (or co-determine) institutions. Stakeholders are local individuals who are affected by the institution and the choices (Freeman, 1984; Reed, 2008). I focus on the local level and not societal wide participation, such as devolution and decentralization processes (cf. Agrawal and Ostrom, 2001).

There are numerous classifications of participation. I focus on two dimensions: degree of involvement and timing. The ladder of Arnstein (1969) (and later extensions by others, Reed, 2008) ranks participation by degree of stakeholder involvement and power, where the top rung is majority or full control of decisions. This paper adopts a simplified ranking from weak to strong participation. Weak participation is consultation, where stakeholders inform decision makers. Stakeholders have no direct influence over choices, and the indirect choices have little, if any, impact. A medium level of participation is consent, where stakeholders may veto decisions and thus make constrained choices, with impact. Lastly, strong participation is control, where stakeholders are in the driving seat and make choices under few, if any, constraints, as in Arnstein's top rung.

Stakeholders may be involved at different time stages. First, the initiative can arise from the stakeholders or from the outside. Mansuri and Rao (2013a) distinguish between organic participation, where social movements from below initiate the process, and induced participation, where the initiative is external (but stakeholders are later involved within the set agenda). Second, stakeholders may participate in designing the institution (i.e., setting the rules). Third, stakeholders can participate in implementing the initiative made in stage one according to the design formed in stage two. The time and involvement dimensions with three stages/degrees each thus create nine cells, as presented in Figure 1.

While these categories are not exhaustive and demarcations blur, such a typology can be useful to understand participation as a means. It particularly allows for applying theories from behavioral economics to explain possible positive effects of participation.

\subsection{Why participation may matter}

From a project proponent's perspective, participation of local stakeholders can be a means to improve an institution's effectiveness (achievement of the set objectives), efficiency (costs of achieving the objectives) and/or equity (fair distribution of costs and benefits). Institutional performance refers to the ability to deliver these three es according to given objectives. This instrumental significance of participation is advocated in many settings, e.g., in organizations (Pierce et al., 2001), in medicine (Hickey and Kipping, 1998) and in marketing (Krugman, 1966).

Related to development and nature conservation institutions, a study of irrigation projects in South India found farmers to be more likely to help maintain field-channels if they had been involved in designing the maintenance plans (Bardhan, 2000). In Belize, local involvement in planning and implementing sanitation projects has led to better maintained school toilets years later (Chatterley et al., 2013). And Buchy and Hoverman (2000, p. 16) argue for "participation as a management tool" in Australian forestry. Tanzania's participatory forest management (PFM) has arguably been somewhat successful in reaching its goal of sustainable forest use (Brockington, 2007; Lund and Treue, 2008; Blomley and Iddi, 2009; Treue et al., 2014). Mansuri and Rao (2013b, p. 6), in their extensive review of the relevant literature, conclude that "greater community involvement seems to modestly improve resource sustainability and infrastructure quality", but that the benefits are unequally distributed. ${ }^{4}$

The effects of participation have also been explored in laboratory experiments. In public good experiments, participants have been shown to be more likely to follow norm behavior under a sanctioning mechanism when the mechanism is chosen through a referendum than when it is imposed externally (Tyran and Feld, 2006; Sutter et al., 2010; Markussen et al., 2013). Dal Bó et al. (2010) aim investigate sense of ownership, which they refer to as the "endogeneity premium effect." In their lab experiment, participants vote on their preferred policy in prisoners' dilemma experiments, but some groups still have the policy imposed randomly. By comparing those who voted for the policies in the group that chose the policy and in the group that had the policy imposed, they control for unobservables determining selection. They find a positive effect of choice, and that the effect is both due to the selection effect and a mere effect of the choice. A potential issue with the design is the comparison between participants

\footnotetext{
4 Possible negative effects of local participation are not discussed (cf. Baland and Platteau, 1996; Cooke and Kothari, 2001; Brockington, 2007; Lund and Saito-Jensen, 2013).
} 
who vote and subsequently choose a policy and participants who vote, but whose vote is disregarded and the policy (they voted for) is implemented exogenously. Participants in the latter group not only have the policy imposed, they are overruled (although with the policy they voted for). Overruling might for instance reduce the policy's credibility and thus the ability to coordinate behavior. These studies are also in abstract form and conducted in laboratories, ignoring possible context-relevant effects (Henrich et al., 2001; Harrison et al., 2007; Maddux et al., 2010; Voors et al., 2012; Handberg and Angelsen, 2015).

Table 1. Mechanisms through which participation may improve institution outcomes

\begin{tabular}{|c|c|c|}
\hline Mechanism & Argument & References \\
\hline Knowledge & $\begin{array}{l}\text { More and better } \\
\text { knowledge creates } \\
\text { better institutions }\end{array}$ & $\begin{array}{l}\text { (Ostrom, 1990; Chambers, 1994; Pretty, } \\
\text { 1995; Rodrik, 2000; Dietz et al., 2003; } \\
\text { Reed, 2008; Schultz et al., 2011) }\end{array}$ \\
\hline Empowerment & $\begin{array}{l}\text { Stakeholders are } \\
\text { better equipped }\end{array}$ & $\begin{array}{l}\text { (Bamberger, 1991; Buchy and Hoverman, } \\
2000 \text { ) }\end{array}$ \\
\hline $\begin{array}{l}\text { Transparency \& } \\
\text { accountability }\end{array}$ & Improves governance & (Ribot, 2008; Schultz et al., 2011) \\
\hline Dialogue & $\begin{array}{l}\text { Facilitating dialogue } \\
\text { reduces conflicts }\end{array}$ & (Innes, 1996; Conley and Moote, 2003) \\
\hline $\begin{array}{l}\text { Sense of } \\
\text { ownership }\end{array}$ & $\begin{array}{l}\text { Stakeholder support } \\
\text { increases through } \\
\text { involvement }\end{array}$ & $\begin{array}{l}\text { (Buchy and Hoverman, 2000; Reed, 2008; } \\
\text { Dal Bó et al., 2010; Schultz et al., 2011; } \\
\text { Marks and Davis, 2012) }\end{array}$ \\
\hline
\end{tabular}

Table 1 summarizes key arguments advanced for participation having positive effects on institutional performance in five mechanisms. First, by involving local stakeholders in project design, local knowledge that may be hidden to external "experts" is accessed, thus creating locally adapted institutions that rely on deeper knowledge and more updated information (both in setting objectives and creating measures). Second, the process of including local stakeholders is empowering, which helps to better sustain the institution (as stakeholders are better equipped with skills, power, knowledge, etc.). Third, as participation requires some degree of openness in the decision making process it improves the transparency and holds the project proponents more accountable, which help create more efficient institutions. Fourth, dialogues between stakeholders and project proponents, and among stakeholders, reduce the number and intensity of conflicts, and thus reduce the costs related to solving such conflicts. Fifth, local participation induces "sense of ownership" among the stakeholders, as described in Section 1.

\subsection{A typology}

Summarizing Subsections 2.1 and 2.2, local participation, at the initiative, design and/or implementation stage, can improve institutional effectiveness, efficiency and/or equity through one or more of the five listed mechanisms (Figure 1). The effect of the mechanism(s) on institutional performance may vary by stage, level of participation and context.

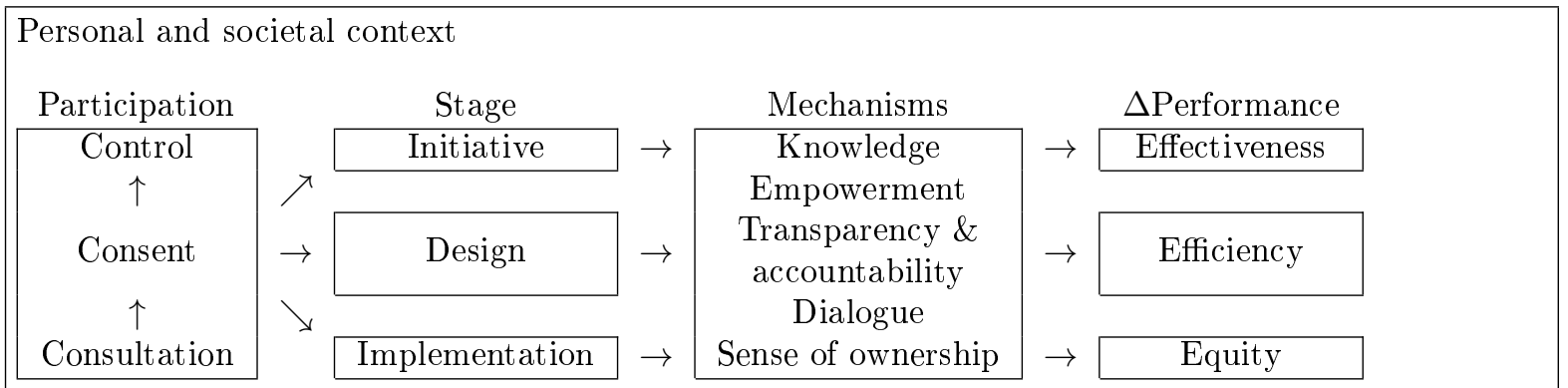

Figure 1. Participation as a means 
The sense of ownership hypotheses, although often unspecified, could also apply to any of the three stages and outcomes. Stakeholders may sense ownership of the idea to be initiated, of the design process, or of the implementation. These three senses of ownership may affect the effectiveness, efficiency and/or equity differently, and may also interact with the context and the other mechanisms. Section 4 aims to test the effect of participation (choice) in the design stage, inducing a sense of ownership among local stakeholders, which improves institutional effectiveness.

\section{Sense of ownership - a behavioral perspective}

Following Section 2, stakeholders making choices with consequences is integral to (strong) participation. Both consent and control (Figure 1), involve stakeholders who make choices that impact the initiative, design and/or implementation of the institution. Sense of ownership entails both choice inducing ownership, and ownership improving institutional performance. Both are psychological effects, and the following attempts to find a theoretical justification in the related literature.

The hypothesis does not normally refer to legal ownership of physical objects. A useful distinction is between real ownership and symbolic ownership (Etzioni, 1991). The former applies strictly to objects, it involves scarcity and it often relates to legal property rights; two parties cannot own an object unless they split the property right. The latter form of ownership mostly refers to non-objects, which can be "owned" by multiple parties simultaneously. For instance, symbolic ownership of one's hometown, does not necessarily affect others ownership of the same. Symbolic ownership is an attribute of our minds, while real ownership also exists outside our minds. Sense of ownership, as interpreted here, induces symbolic ownership (of an organization, project, policy, etc.) to stakeholders.

Subsection 3.1 explores how ownership increases appreciation of what is owned. The literature is more developed on effects of real ownership of physical objects, but the effects also relate to less tangible objects and ownerships, and some research has explored this. Subsection 3.2 links the effects of owning to choosing, to understand how choosing may induce ownership.

\subsection{The endowment effect}

The endowment effect is a well-established effect within economics and psychology; ceteris paribus, we tend to value an object more when we possess it (Kahneman et al., 1991). The seminal experiment is that participants value coffee mugs higher if endowed with them than if not (Thaler, 1980). Not limited to concrete objects, discrepancies in people's willingness to accept (WTA) and willingness to pay (WTP) have been found for more abstract goods, such as clean air, bitter-unpleasant taste experiences, local tree density, job health risk and work effort (Horowitz and Mcconnell, 2002; Norton et al., 2012).

The cause for the endowment effect is less certain than its presence. Morewedge and Giblin (2015) summarize the literature in six possible (not necessarily mutually exclusive) drivers. First, loss aversion: as losses loom larger than gains, the cost of departing with a good is higher than the benefit of acquiring the same good (Kahneman and Tversky, 1979; Köszegi and Rabin, 2006). Second, evolutionary advantage: the endowment effect improves one's bargaining position, thus favoring individuals with stronger endowment effect preferences (Huck et al., 2005). Third, method driven: in a bargaining situation "sellers" have an incentive to increase stated WTA and "buyers" have an incentive to decrease stated WTP (Plott and Zeiler, 2007). Fourth, reference prices: one adjusts WTA/WTP to the (fair) reference price, e.g., the market price for the given good (Weaver and Frederick, 2012). Fifth, biased information processing: sellers weigh or notice attributes of the good in question more strongly than buyers do (Carmon and Ariely, 2000). Sixth, psychological ownership: mere (imagining to be) owning a good, independent of being seller or buyer, increases one's valuation of the good (Brehm, 1956; Symons and Johnson, 1997; Gawronski et al., 2007; Morewedge et al., 2009). Two possible explanations of psychological ownership is associative self-anchoring (Belk, 1988; Gawronski et al., 2007; Weiss and Johar, 2013) and cognitive dissonance (Brehm, 1956). These two explanations are elaborated below.

\subsection{Owning and choosing}

The endowment effect relates to choosing. One tends to value what one chooses (e.g., to own) more than what one chooses away, also when controlling for the confounding factor that we choose what we value highest (Brehm, 1956; Johansson et al., 2005; Gawronski et al., 2007; Morewedge et al., 2009). Examples include horse bettors whose confidence to win on a given horse increases after placing their bet (Knox and Inkster, 1968; Akerlof and Dickens, 1982), experiment participants who implicitly value 
pictures as being more attractive after having chosen to keep them than before their choice was made (Gawronski et al., 2007), and students who value an additional mug more than the first mug (controlling for complementarities and diminishing marginal utility) (Morewedge et al., 2009).

Of the six potential causes summarized above, biased information processing and psychological ownership, in the form of associative self-anchoring or cognitive dissonance, are relevant in the context of choosing symbolic ownership. The remaining causes relate to losing or giving up what is chosen, which is not applicable to choice in local participation. The following discusses biased information processing, associative self-anchoring and cognitive dissonance in more detail.

Biased information processing: According to this theory, owners are in another framing than non-owners and thus weigh attributes of the good in question differently. This difference in weighting is biased towards considering the good more favorable when owned. For instance, ticket-owners of an upcoming basketball game consider more the importance of the game and the desirability of attending it than non-owners, who tend to consider the list price and other costs of attending (Carmon and Ariely, 2000). A similar tendency has been found among the well-researched coffee mug owners (Johnson et al., 2007). Related to sense of ownership in interventions, stakeholders who participate in design and implementation become owners and thus focus more on the positive aspects of the given institution than non-owners do. This favorable evaluation by the participants then leads to more support for the given institution.

Associative self-anchoring: This alternative explanation focuses on the association between oneself and the goods one chooses. Because one associates oneself with the goods one owns, and as one in general evaluates oneself positively (or wants to do so, Benabou and Tirole, 2002), one values the goods one owns more favorably (Belk, 1988; Gawronski et al., 2007; Weiss and Johar, 2013). That we tend to implicitly self-evaluate ourselves positively implies that we non-consciously think of our self-concept and self-esteem in positive terms (Bosson et al., 2000; Greenwald and Farnham, 2000; Gawronski et al., 2007; Stieger et al., 2012). Choosing something creates a positive association between ourselves and what is chosen. Participants in institutional design make choices which associate their positive self-evaluations to the given institution. This in turn increase support for the institution. The related literature suggests methods to elicit implicit self-evaluation. The most common method is the Initial Preference Task, which asks individuals to rate letters on a scale of likability or attractiveness (Nuttin, 1987; Greenwald and Farnham, 2000; Koole et al., 2001; Gawronski et al., 2007; Stieger et al., 2012). The consistent finding that individuals rate letters in their names more favorable than non-name letters is taken as an indication of positive implicit self-evaluation.

Cognitive dissonance: The third possible driver is cognitive dissonance, and more specifically post-decision dissonance (Festinger, 1957): One tries to justify choices by increasing the perceived value of the chosen alternative and/or decrease the perceived value of the unchosen alternative(s) (Brehm, 1956; Morewedge and Giblin, 2015). When making a choice, we also choose away something else, thus creating a potential cost of regret. To compensate for this discomfort, we tend to become more positive to what we have chosen (or become more negative to what we have not chosen). As this justification becomes more necessary the more equal the choice alternatives are, cognitive dissonance should be stronger the more equally valued the alternatives originally were. The theory therefore predicts that stakeholders' participation in institutional design and implementation, forces more support for the institution because stakeholders wants to justify that they made the right choice.

The following presents an experimental study aiming to test the effect of choice on institutional performance in a specific context, and to test each of the three potential psychological mechanisms described above. The assumption is that the favorable evaluation of choosing institution, relative to having the same institution imposed, increases institutional performance.

\section{Experimental study}

\subsection{The context: REDD + and Tanzania}

REDD + (Reducing Emissions from Deforestation and forest Degradation, and enhancement of forest carbon stocks in developing countries) is an umbrella term for actions aimed to reduce carbon emissions from forest use in developing countries (Angelsen, 2009). It is seen as a relatively quick and cheap approach to mitigate climate change (Stern, 2006), with increasing attention and funds being received at the global level since its launch in 2007. More than USD 9.8 billion was pledged in aggregate between 2006 and 2014, with Norway as one of the most prominent donors (Norman and Nakhooda, 2014). 
The core idea of REDD + is payment for environmental services (PES), i.e., forest users (countries, communities, individuals) are compensated for reduced emissions from estimated baselines (Angelsen, 2009). In implementing the forest conservation initiatives, however, a wide range of policies are likely to be applied, such as participatory forest management (PFM), where local communities are (to varying extents) responsible for local forest management decisions (Angelsen, 2009; Green and Lund, 2015; Scheba and Mustalahti, 2015). In fact, the strategy for the UN-REDD Programme (2011, p. 5) emphasizes that "stakeholder participation and engagement is critical to developing viable REDD + strategies and implementation frameworks." The framework document states that "[...] inadequate mechanisms for effective participation of local communities in land use decisions could seriously compromise the delivery of both local and global benefits and the long-term sustainability of REDD investments" (UN-REDD Programme, 2008, p. 5).

Tanzania has a population crucially dependent on local forest use, in particular as a source of fuel wood (World Bank, 2008; TNRF, 2009) and has one of the highest deforestation rates in Africa (FAO, 2011). The country is one of the most active REDD + countries in Africa, with the first bilateral REDD + agreement with Norway signed in 2008 (Blomley and Ramadhani, 2006; Blomley and Iddi, 2009; Angelsen, 2009). Although local REDD + pilot projects include result-based incentives, the Tanzania-Norway agreement is not performance based and have strong elements of traditional aid cooperation (Angelsen, 2016). Local NGOs and participatory forest management (PFM) have been key elements from the start (Blomley et al., 2011; Mwakalobo et al., 2011; URT, 2012; Sills et al., 2014; Treue et al., 2014; Scheba and Mustalahti, 2015).

\subsection{Study area and sampling}

During the period September-November 2014, we conducted experiments and gathered data in three regions of Tanzania: Geita located in the tropical northwest of the country, Kilimanjaro located in the northeast and Lindi in the arid southeast of the country. In each of the three regions, we selected five villages in collaboration with district authorities or local NGOs. The villages vary in population size, accessibility (distance to nearest major road, distance to closest town and availability of public transport), distance to forest frontier, size of the nearest accessible forest, involvement in PFM, exposure to external forest conservation project, and major livelihoods (Appendix I). The selection of regions and villages capture variation in attributes and thus make the results more generalizable.

Within each village, we randomly selected 32 participants by drawing from the village registry (an already existing list of the households in the village, but which often needed to be updated). Each participant was then randomly assigned to a specific session with a predetermined treatment. The invitation stated that they would be compensated with a small, unspecified amount of money. With eight $^{5}$ participants in 60 experiment session the total sample is 480 participants.

Appendix I presents descriptive statistics at the individual level and compares the mean values for the groups (by treatments, see below). No significant differences across groups indicates successful random sampling. 6

\subsection{Experimental design}

We conducted a framed field experiment (Harrison and List, 2004): the sample (local forest users) and the framing (local forest use and conservation) are relevant. The design draws on Cardenas (2004) and Handberg and Angelsen (2015). In each session, the eight participants are collectively endowed with a stock of 80 cardboard trees. Each tree, depicted in Figure 2, privately pays TZS 100 (USD 0.06) to the participant who harvests it. ${ }^{7}$ In each of nine rounds, the participant privately decides how many trees to harvest, with five trees being the upper limit. 8 The participant has to physically tip each tree to indicate harvest, observed by an enumerator, who takes note and replants the harvested forest, such that the next participant faces the same forest size (decisions are made as if simultaneous). At the end of the harvest round, the aggregate number of trees harvested is revealed to the group and removed from

\footnotetext{
5 From precedence set by Ostrom et al. (1994, p. 108), with the justification that it "approximates some of the characteristics of larger groups or conflict-ridden small groups."

6 See questionnaire in Appendix IV for a better understanding of the variables.

7 Daily wage for casual labor in rural Tanzania roughly corresponds to 15 trees. The payoffs are accumulated and paid at the end of the session. Participants received no show-up fee, but a minimum payment of TZS 2000 was practiced.

8 At forest stocks below 40 trees, the upper limit is determined by $\left\lfloor\frac{S_{t}}{8}\right\rfloor$, i.e., the forest stock $\left(S_{t}\right)$ divided by the number of participants and rounded down to nearest whole number. The information is given in the form of the upper limit table given in Appendix IV. The maximum forest size is 160 trees.
} 
the forest. Thereafter, the forest grows by two trees for every ten trees standing. The sessions lasts for nine rounds, or until the forest depletes to less than eight trees. The number of rounds and all other parameters are made known to the participants. ${ }^{9}$

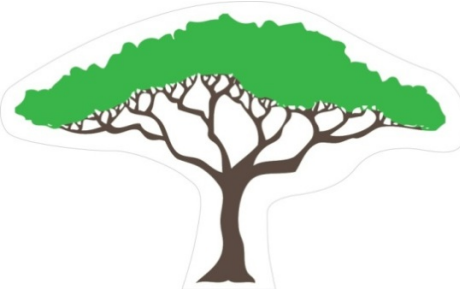

Figure 2. Tree used as token $(6 \mathrm{~cm}$ tall $)$

\subsection{Treatments}

In a $2 \times 3$ between-groups design, the sessions were randomly selected into choice (192 participants) and no-choice (192 participants), in addition to a control group (96 participants). Under the two treatment groups, sessions were again randomly selected into three sub-group treatments, 20\%, 60\% and 100\% PES (see Table 2).

In the choice treatment, participants were asked to choose one of two additional payment schemes (in addition to the TZS 100 per tree harvested) before the first round: (i) sell 40 of the trees immediately for TZS 50 each, implying a private payment of TZS 250 before the session starts, with an initial forest size of 40 (instead of 80) trees, or (ii) receive 20/60/100 TZS for each tree not harvested in each round, i.e., the difference between the upper limit and the harvested amount of trees. One of the three payments $(20 \%, 60 \%$ or $100 \%$, measured relative to the value of a harvested tree) was presented at random (with examples for clarification), creating the three sub-treatment groups. ${ }^{10}$ As the payments are incentives for decreasing forest use, scheme (ii) simulates a payment for environmental services (PES) scheme, and is presented as such. The participants were given three minutes to discuss privately within the group, before an anonymous referendum was held. The scheme was then chosen by majority vote.

In the no-choice treatment, participants had scheme (ii) imposed exogenously (with one of the three payment levels). These participants were also allowed to communicate in private as a group for three minutes before the first harvest round, to control for communication effect.

In the control group, the participants experienced no PES scheme. Also this group was allowed to communicate in private for 3 minutes before the first round.

Table 2. Treatment design

\begin{tabular}{cccccccc}
\hline & \multicolumn{3}{c}{ Choice } & \multicolumn{3}{c}{ No-choice } & Control \\
\hline PES level & $20 \%$ & $60 \%$ & $100 \%$ & $20 \%$ & $60 \%$ & $100 \%$ & - \\
$N$ participants & 64 & 64 & 64 & 64 & 64 & 64 & 96 \\
\hline
\end{tabular}

Besides sense of ownership, Table 1 presents four other potential mechanisms through which participation can improve institutional performance. The presented experimental design controls for these potential confounding effects. First, local knowledge cannot be used to select the treatment best suited to the group, as all sessions chose the superior scheme (ii). This lack of selection also ensures that choice has no impact on payoffs. Second, participants in the choice treatment are not given any information or benefits which would empower them more than others. Third, there are no additional transparency under the choice treatment than in others. Fourth, participants in the choice and no-choice treatment groups and the control group are all allowed to communicate in private for three minutes once, thus creating the same conditions for dialogue. ${ }^{11}$

\footnotetext{
9 See Appendix IV for participant instructions.

10 For instance, harvesting three trees with an upper limit of five trees and $60 \%$ PES implies a private earning of: $T Z S 100 * 3+T Z S 60 *(5-3)=T Z S 420$ in the given round.

11 Another possible counterfactual is the decoy effect. The literature on irrelevant alternatives is dominated by the idea of asymmetrical dominance (e.g., Huber et al., 1982; Ariely and Wallsten, 1995), where there is an effect on choice of an irrelevant alternative. The effect is, however, found in choice settings where introducing an irrelevant alternative dominated by one option, but not necessarily dominated by others - increases the propensity to choose the option which dominates the irrelevant option. The design in this paper is different as there are only two and rather different options.
} 
As presented in Section 3, the treatment relies on the assumption that choosing is an integral part of participation and that it is the choice that creates sense of ownership. The treatment also relies on the assumption that the participants perceive it as an actual choice, which will be discussed in Section 6 .

\subsection{Theoretical predictions}

As in the design of Handberg and Angelsen (2015), the social dilemma is whether to maximize own payoffs by harvesting the maximum amount of trees each round, or maximize the total payoffs for the group by harvesting fewer trees.

Under both $0 \%$ and at the $20 \%$ PES, the optimal decision for a payoff maximizing participant is to harvest the maximum number trees which are allowed in each round, independent of the choices of the other participants in the session (the Nash equilibrium). Under $60 \%$ PES, the optimal decision depends on the beliefs the participant has about the decisions of the other participants in the same session. If a participant believes the others to be either selfish (harvest close to the maximum) or strongly pro-social (harvest close to nothing), the optimal decision is to harvest the maximum amount of trees allowed in each round. If the participant believes that the mean decision of the others is close to neither corner, the optimal decision is to harvest less. Under $100 \%$ PES, there is no incentive to harvest any trees, independent of the choices of others.

Choosing PES scheme or having the same scheme imposed should not affect the harvest decision of the participants, as the parameters are identical. The sense of ownership hypothesis, however, suggest that participants who choose the PES scheme are more positive to the intention of the scheme and should thus harvest less (increase effectiveness). Theory and earlier studies suggest that the payment schemes will perform better when chosen than when imposed, i.e., participants harvest less under choice than under no-choice. The sense of ownership hypothesis in this experimental setting is:

H1 Participants harvest more trees under no-choice than under choice

Biased information processing predicts that participants who choose the PES scheme, evaluate PES more favorable than others, which makes the PES scheme more effective among participants in the choice group. In the post-experiment interview, we indirectly asked the participants about their perceptions of the PES concept (questions 24-26, Appendix IV). On a scale from 1 to 5 , where 5 is strongly agree and 1 is strongly disagree they responded to the following statements: "it is right that those who benefit from the clean air that our forests produce, contribute to conserving the forest" (normative evaluation), "it is not proven that paying for living trees decreases deforestation" (factual evaluation), "paying for living trees makes other forest use considerations less important; like tradition, culture and religion" (PES and crowding-out). The hypothesis is:

H2 Choice induces more positive participant evaluations of PES schemes and the treatment effect is stronger among these participants

Associative self-anchoring predicts that the positive effect is stronger the more positive the participant evaluates themselves. In the post-experiment questionnaire, participants were asked about their first, intuitive reaction to four letters, which they rated on a scale from one to five (strongly dislike, dislike, ambivalent, like, strongly like) (question 32, Appendix IV). Participants were (orally) presented with the letters $E$ and $R$, then the first letter in their stated first name and one letter not in their stated names. The theory predicts that the participants on average rate the letter in their first name more favorable than the letter not in their name. Similarly, participants with names which includes $E$ and/or $R$, should on average rate the letter(s) more favorable than participants whose name does not include the letter(s). The theory predicts that participants who rate letters in their own name highly (in absolute terms or relative to the rating of other letters), should have a stronger sense of ownership. The treatment effect should thus be stronger among the positive implicit self-evaluators, implying the following hypothesis:

H3 The effect of choice is stronger among participants who score higher on implicit self-evaluation

Cognitive dissonance predicts that the positive effect is stronger the more equal the options are, as the potential for cognitive dissonance is stronger here. This implies that the treatment effect of choice is stronger the lower the PES level is. The specific hypothesis is:

H4 The effect of choice is stronger among participants under 20\% PES than under $60 \%$ and $100 \%$ PES

Also, if relevant, asymmetrical dominance should strengthen the effect of the treatment. As will be revealed, the treatment effect is weak. 
A plausible outcome measure for a forest conservation intervention is decrease in extractive forest use. The following will therefore consider reduction in number of harvested trees as the measure of success of the payment scheme. As the upper limit is relative to the forest size, analyses at absolute numbers could create biases. A harvest rate [0-1] indicating the number of harvested trees relative to the upper limit is therefore used. ${ }^{12}$

\section{Results ${ }^{13}$}

\subsection{Sense of ownership}

Table 3 summarizes the individual mean harvest rates for the aggregated treatment and control groups. Here and in the following tables, the 17 participants voting for scheme (i) are excluded. ${ }^{14}$

Table 3. Mean individual harvest rates

\begin{tabular}{cccc}
\hline Group & Mean & & $N$ \\
\hline Control & 0.570 & $(0.060)$ & 96 \\
No- choice & 0.328 & $(0.044)$ & 192 \\
Choice & 0.291 & $(0.031)$ & 175 \\
\hline Session clustered standard errors in \\
parentheses.
\end{tabular}

Even without treatment, the mean harvest rate is lower than the Nash equilibrium $(0.57<1) .{ }^{15}$ The mean harvest rates under the two treatment groups, no-choice and choice, are both significantly lower than the mean harvest rate under the control group. The means reported are across the three payment levels. The mean harvest rates in the two treatment groups are not significantly different from each other $(p=0.488),{ }^{16}$ indicating that there is no impact of choosing the payment scheme. The initial test reveals no support for H1.

\subsection{Biased information processing}

The biased information processing hypothesis predicts that participants who chose the PES scheme should evaluate PES more favorable than participants who had the scheme imposed. The three elicited PES evaluations - normative evaluation, factual evaluation, and PES and crowding-out - ranks PES perception from 1 to 5 (questions 24-26, Appendix IV). Table 4 summarizes the evaluations separately by the choice treatment. It reveals that there are no significant differences between the group's mean evaluation in neither of the three statement. There is therefore no support for the first requirement of $\mathrm{H} 2$, and the hypothesis is rejected.

Table 4. Participants' PES evaluation by the choice treatment

\begin{tabular}{cccc}
\hline Statement & No-choice & Choice & $p$-values \\
\hline Normative evaluation & $2.333(0.110)$ & $2.200(0.110)$ & 0.380 \\
Factual evaluation & $3.526(0.082)$ & $3.600(0.075)$ & 0.865 \\
PES and crowding-out & $3.453(0.072)$ & $3.377(0.082)$ & 0.577 \\
\hline$N$ & 192 & 175 &
\end{tabular}

Standard errors in parentheses. $p$-values produced by Wilcoxon ranksum tests.

\footnotetext{
12 For instance, harvesting two trees from a forest of 39 trees (upper limit of four) and harvesting one tree from a forest of 17 trees (upper limit of two) implies the same harvest rate: 0.5 .

13 The following tests multiple hypotheses, which could lead to type I errors if not corrected for. As will be apparent, there are no (false) positives and thus no need for corrections.

14 The observations are removed as sense of ownership, according to the three presented theories, should only arise for those who choose the scheme that is implemented. For impact assessment purposes, it could be interesting to analyze the effect in aggregate; stakeholders likely vote differently. Appendix III show that although nay-sayers harvest significantly more, including them produces similar results and the same conclusions.

15 The harvesting is still unsustainable, as the forest stock decreases through the nine rounds in eleven sessions (of twelve) and depletes in six of these.

16 All mean comparisons in the paper are bootstrapped (Efron and Tibshirani, 1993) $t$-tests, as this does not require distribution assumptions and the number of repetitions (9999) ensures reliable power (probability to reject equality of means) (Davidson and MacKinnon, 2000; Moffatt, 2016). The standard errors are clustered at the session level.
} 


\subsection{Associative self-anchoring}

The associative self-anchoring hypothesis predicts that (i) the participants' mean implicit self-evaluation should be positive, and (ii) that the treatment effect is stronger for participants with positive implicit self-evaluation than for others. Table 5 presents the mean implicit self-evaluation of the participants. The table reveals that participants evaluate the letters $E$ and $R$ more favorable if it is the first letter in their stated first name. The participants also evaluate the first letter in their first stated name more favorable than a letter not in their name (see Appendix II for the distribution of letters). The finding is not as clear in their evaluations of $E$ and $R$ when their stated names include the letters elsewhere to when their names do not include the letters; $R$ is evaluated more favorable, but $E$ is not. Taken together, the data supports previous findings in that people tend to evaluate letters in their own name more favorable than other letters (e.g., Nuttin, 1987; Hoorens et al., 1990; Koole et al., 2001; Gawronski et al., 2007), which supports prediction (i). ${ }^{17}$

Table 5. Mean implicit self-evaluations by letter

\begin{tabular}{cccc}
\hline & If first letter $/$ in name & If letter not in name & $p$-values \\
\hline$E$ (as first letter) & $4.172(0.205), N=29$ & $3.601(0.054), N=451$ & 0.002 \\
$R$ (as first letter) & $4.690(0.087), N=29$ & $3.506(0.056), N=451$ & 0.000 \\
$E$ (in name) & $3.629(0.067), N=299$ & $3.646(0.085), N=181$ & 0.921 \\
$R$ (in name) & $3.775(0.081), N=200$ & $3.436(0.071), N=280$ & 0.001 \\
Random letter & $4.366(0.048), N=479$ & $3.613(0.055), N=479$ & 0.000 \\
\hline Standard errors in parentheses. $p$-values produced by Wilcoxon ranksum tests. Random letter refers \\
to two letters randomly chosen among those in the participant's name and those not in the name.
\end{tabular}

Table 6 tests for associative self-anchoring by the interaction effect of the choice treatment and positive implicit self-evaluation on individual mean harvest rates. Model (1) defines positives as those who value the letter in their name positively (like or strongly like on the five-point Likert scale) while the remainders constitute the negatives and neutrals (strongly dislike, dislike or ambivalent). Model (2) defines positives as those who value the first letter in their name more favorable than the letter not in their name, and the others as negatives and neutrals.

Table 6. Testing for associative self-anchoring

\begin{tabular}{cllll}
\hline & \multicolumn{2}{l}{ (1) Absolute positive } & \multicolumn{2}{l}{ (2) Relative positive } \\
\hline Choice & -0.104 & $(0.096)$ & -0.091 & $(0.067)$ \\
Positive & -0.094 & $(0.074)$ & -0.084 & $(0.049)$ \\
Choice* positive & 0.068 & $(0.080)$ & 0.086 & $(0.059)$ \\
Constant & $0.323^{* * *}$ & $(0.055)$ & $0.297^{* * *}$ & $(0.030)$ \\
\hline$R^{2}$ & \multicolumn{2}{c}{0.103} & 0.107 \\
$N$ & \multicolumn{2}{c}{367} & 367 \\
\hline Dependent variable: individual mean harvest rate through the session. \\
Session clustered standard errors in parentheses. *****,*: significant \\
at the 1, 5 or 10\% level. Includes village dummies (not reported).
\end{tabular}

With no significant impact on mean harvest rates of the choice in Table 6 , neither among the positives nor among the neutrals/negatives. There is thus no support for H3.

\subsection{Cognitive dissonance}

The cognitive dissonance hypothesis predicts that the treatment effect is stronger the lower the PES level is, as this implies that the two payment schemes presented to the participants are more equal. ${ }^{18}$ Table 7 reports the mean harvest rates by the three payment levels under no choice and choice.

\footnotetext{
$1724 \%$ of the participants stated to be illiterate. Since the letters were presented orally and all participants knew their own name, I assume that literacy is not required for the association.

18 The number of participants voting for the inferior payment scheme under the three payment levels would be an indication of the equality of options. When presented with the $20 \%$ payment level, 8 (of 64 ) participants voted for the other payment scheme, while 4 (of 64) and 5 (of 64) participants voted for the other payment scheme when presented with the $60 \%$ or $100 \%$ payment scheme respectively.
} 
Table 7. Mean individual harvest rates

\begin{tabular}{ccccccc}
\hline Group & \multicolumn{2}{c}{$20 \%$} & \multicolumn{2}{c}{$60 \%$} & \multicolumn{2}{c}{$100 \%$} \\
\hline No-choice & 0.523 & $(0.057)$ & 0.337 & $(0.059)$ & 0.125 & $(0.028)$ \\
Choice & 0.424 & $(0.048)$ & 0.310 & $(0.023)$ & 0.145 & $(0.025)$ \\
\hline$p$-values & 0.214 & \multicolumn{2}{c}{0.672} & 0.611 \\
$N$ & 120 & \multicolumn{2}{c}{124} & \multicolumn{2}{c}{123} \\
\hline
\end{tabular}

Session clustered standard errors in parentheses.***,**,*: significant

at the 1,5 or $10 \%$ level.

Investigating the means by the three payment levels reveals that the participants respond to increasing the PES payment. Comparing the means within each PES level reveal no significant impact of the choice treatment at any of the three PES levels.

Further investigating, Table 8 reports the implied harvest rate of each participant decision regressed on treatment and control variables. $x_{i t-1}$ is the lagged harvest rate decision and $\frac{\sum x_{j \neq i, t-1}}{7}$ is the lagged average harvest rate decisions of the other seven participants in the same session. Village fixed effects are included to control for possible biases in that the distribution of treatments is not identical in each village, and round dummies are included to control for time trends (not reported). There is no significant impact of choice on the harvest decisions of the participants in any of the three PES levels, thus leaving no support for $\mathrm{H} 4$.

Table 8. Regressing choice level harvest rate on treatments and controls

\begin{tabular}{cll}
\hline Variable & \multicolumn{2}{c}{ Harvest } \\
\hline Choice & -0.043 & $(0.031)$ \\
$60 \%($ relative to $20 \%)$ & $-0.081^{* *}$ & $(0.033)$ \\
$100 \%$ (relative to $20 \%)$ & $-0.129^{* * *}$ & $(0.029)$ \\
Choice* $60 \%$ (relative to $20 \%$ choice) $^{*}$ & 0.049 & $(0.039)$ \\
Choice* $100 \%$ (relative to $20 \% *$ choice) $^{*}$ & 0.028 & $(0.034)$ \\
$x_{i, t-1}$ & $0.648^{* * *}$ & $(0.033)$ \\
$\frac{\sum x_{j \neq i, t-1}}{7}$ & 0.013 & $(0.069)$ \\
Constant & $0.132^{* *}$ & $(0.050)$ \\
\hline$R^{2}$ & 0.477 & \\
$N$ & 2687 & \\
\hline
\end{tabular}

Session clustered standard errors in parentheses.***,**,*: significant at the

1,5 or $10 \%$ level. Includes village and round dummies (not reported).

\section{Discussion}

In the presented framed field experiment there is no significant impact on institutional effectiveness (measured as decreased forest use) of allowing participants to choose a PES scheme relative to imposing the same scheme. Examining the data by three theories explaining the possible effect - biased information processing, associative self-anchoring and cognitive dissonance - finds little impact of the choice treatment. There are at least three possible explanations for the results. The following subsections discuss each.

\subsection{No significant sense of ownership in this context}

One explanation is that the sense of ownership hypothesis does not apply in the context of incentive based forest conservation among local forest users in Tanzania. The lack of a significant result could simply be due to the effect not being present. The sense of ownership hypothesis might underestimate the rationality of Tanzanian forest users; they support good policies and oppose what are considered bad policies, independent of the source of origin or design.

The specific context of the empirical test is important. Tanzania has a history of decentralized forest management, also at the village level (Blomley and Ramadhani, 2006; Lund and Treue, 2008). The sampled participants should thus be familiar with participation in the three stages of Figure 1. Still, 
choices tend to be made by village leadership, such as the forest committee, not directly by the "average forest user" (Lund and Treue, 2008). Unfortunately the sub-sample of village leaders is too small for clear inference.

The treatment also investigates the hypothesis in the context of incentive based forest conservation. The PES scheme is a particular institution that leaves more freedom to the forest user than for instance a command and control institution. Previous experimental studies find a dividend of democracy in more constraining institutions. No observed effect in this context does not necessarily imply that there is no effect under other institutional arrangements. Furthermore, although there are REDD + pilot projects in Tanzania, the initiative is unknown to most forest users. Inability to properly relate to the chosen PES scheme in the experiment might reduce the impact of sense of ownership.

Lastly, the treatment seeks to test for participation in the design stage. The sense of ownership hypothesis could for instance apply stronger in the initiative stage than in the design stage. The hypothesis could also have stronger impact on efficiency or equity than effectiveness.

\subsection{Design issues}

A necessity for rejecting the sense of ownership hypothesis in this context is good treatment validity, i.e., participants' response to the treatment is predictive for real life responses of participation in designing PES schemes (Handberg and Angelsen, 2015).

The treatment relies on the assumptions that choice is an integral part of local participation and that the potential sense of ownership works through choice. The latter assumption is supported by theories within psychology and behavioral economics, and these specific theories are tested. The former assumption is supported by scholars on participation (e.g., Arnstein, 1969; Pretty, 1995; Cornwall, 2008; Reed, 2008) who emphasize that good participation involves local stakeholders in decision-making processes.

Although the participants are presented with a choice, the choice treatment could be too weak, which may lead to a type II error. Allowing the participants to choose between two payment schemes, where one is inferior to the other, has the desirable attribute that it controls for selection effects. The cost is that the treatment presents a rather easy choice; only minor cognitive efforts are necessary to infer that one is preferred over the other. The participants can feel (rightly so) that they make no real choice.

An additional caveat is that the harvest rates are low, even under no and low PES. This naturally limits the improvement potential of the choice treatment. Still, mean harvest rates under $60 \%$ and $100 \%$ PES are significantly lower than the mean under $20 \%$ PES, indicating that there is some improvement potential.

\subsection{Weak vs. strong participation}

Related to the weak treatment caveat, sense of ownership may be dependent on the degree of real influence the stakeholders exercise through their choice. The ranking in Figure 1 defines control as strong participation, and consent and consultation as weaker forms of participation.

The choice in the experiment is informed and free, but one option is clearly superior to the other. An obvious choice creates little potential impact by each individual choice. The choice is also constrained to the two payment schemes, indicating that the degree of participation is arguably closer to "consent" than "control." The lack of support for the sense of ownership hypothesis could thus be due to the weak form of participation implied by the treatment. Under $20 \%$ PES, the choice should be perceived as less obvious since the options are more similar than under $60 \%$ and $100 \%$ PES. Although insignificant, a decreasing difference in mean harvest rates by choice and a reversal of difference would indicate an effect of choice when the options of the choice are more equal. Both cognitive dissonance (Brehm, 1956; Morewedge and Giblin, 2015) and associative self-anchoring (Gawronski et al., 2007) predict stronger effects of choosing with higher cognitive efforts.

The lack of a clear overall treatment effect (and positive findings of others, presented in Subsection 2.2 ) could thus be an argument for stronger participation. Weak participation, such as participatory rhetoric without actual participation, could then be not only immoral, it could also, from a project proponent's viewpoint, be a cost with no benefits. In contrast, strong participation might not only be an end in itself, but also have positive effects on institutional performance.

Participation simply as a management tool is arguably a contradiction in terms. Strong participation implies stakeholders' opportunity to change the rules of the game, without strict constraints by proponents. Sense of ownership may require strong participation to have a real impact and improve institutional performance. 
At the societal level, participation is normally either advocated as an end in itself (e.g., Sen, 1999) or as a means to achieve other ends, such as economic security (e.g., Arnstein, 1969; Sen, 1999). For project proponents on strict budgets with specific goals, these arguments might not motivate a more participatory approach. From the proponentt's viewpoint the latter argument is a positive externality and the former is normative. Research exploring positive effects of local participation on institutional performance (such as the sense of ownership hypothesis) can help incentivize proponents to move higher up on the participation rankings in designing and implementing institutions, and to facilitate more local initiatives.

\section{Conclusion}

Participation of local stakeholders in initiating, designing or implementing institutions is often claimed by scholars and practitioners to improve institutional effectiveness, efficiency or equity, through at least five possible mechanisms. Sense of ownership, as one of these mechanisms, is often advocated within the development and nature conservation communities. Theoretical and empirical justifications remain scarce. Possible theoretical support is found within psychology and behavioral economics, and a few lab experiments on the effects of democracy give empirical support.

The presented experimental study tests the effect of participation in the design stage on institutional effectiveness, through the sense of ownership hypothesis. The results lend no support to the hypothesis in the context of incentive based forest conservation among local Tanzanian forest users.

One possible explanation for the lack of support is that the experiment represents a weak form of participation. An implication is that weak participation is not only problematic when viewing participation as an end, but also as a means to improve institutional performance. The finding questions the view that (weak) participation is a low-cost strategy to establish sense of ownership among local stakeholder, and thus improve performance. The often-observed weak participation of local stakeholders in development and nature conservation institutions in developing countries could thus have little value except pleasing donors and the public.

From the perspective of a project proponent, participation of local stakeholders can be viewed as a means to improve institutional performance, but participation can also be viewed as an end in itself. A better understanding of the sense of ownership hypothesis (and other mechanisms) can help proponents initiate, design or implement more effective, efficient or equitable institutions. In addition, revealing such positive effects of participation creates incentives for stronger and more extensive participation of local stakeholders.

\section{References}

Agrawal, A., 2007. Forests, Governance, and Sustainability: Common Property Theory and its Contributions. International Journal of the Commons 1 (1), 111-136.

Agrawal, A., Ostrom, E., dec 2001. Collective Action, Property Rights and Decentralization in Resource Use in India and Nepal. Politics \& Society 29 (4), 485-514.

Akerlof, G. A., Dickens, W. T., 1982. The Economic Consequences of Cognitive Dissonance. The American Economic Review 72 (3), 307-319.

Alejandro Leal, P., 2007. Participation: the ascendancy of a buzzword in the neo-liberal era. Development in Practice 17 (4-5), 539-548.

Angelsen, A. (Ed.), 2009. Realising REDD+: National strategy and policy options. CIFOR, Bogor.

Angelsen, A., jun 2016. REDD + as Result-based Aid: General Lessons and Bilateral Agreements of Norway. Review of Development Economics.

Ariely, D., Wallsten, T. S., 1995. Seeking Subjective Dominance in Multidimensional Space: An Explanation of the Asymmetric Dominance Effect. Organizational Behavior and Human Decision Processes $63(3), 223-232$.

Arnstein, S. R., 1969. A Ladder Of Citizen Participation. Journal of the American Institute of Planners 35 (4), 216-224.

Baland, J.-M., Platteau, J.-P., 1996. Halting Degradation of Natural Resources: Is There a Role for Rural Communities? The Food and Agriculture Organization (FAO), Rome.

Bamberger, M., 1991. The importance of community participation. Public Administration and Development $11(3), 281-284$. 
Bardhan, P., 2000. Irrigation and Cooperation: An Empirical Analysis of 48 Irrigation Communities in South India. Economic Development and Cultural Change 48 (4), 847-865.

Belk, R. W., 1988. Possessions and the Extended Self. Journal of Consumer Research 15 (2), 139.

Benabou, R., Tirole, J., 2002. Self-Confidence and Personal Motivation. The Quarterly Journal of Economics $117(3), 871-915$.

Blomley, T., Iddi, S., 2009. Participatory Forest Management in Tanzania: 1993-2009. Ministry of Natural Resources and Tourism, Forestry and Beekeeping Division, Dar es Salaam.

Blomley, T., Lukumbuzya, T., Brodning, G., 2011. Participatory forest management and REDD + in Tanzania. World Bank, Washington D.C.

Blomley, T., Ramadhani, H., 2006. Going to scale with Participatory Forest Management: early lessons from Tanzania. International Forestry Review 8 (1), 93-100.

Bosson, J. K., Swann, W. B., Pennebaker, J. W., 2000. Stalking the perfect measure of implicit self-esteem: The blind men and the elephant revisited? Journal of Personality and Social Psychology 79 (4), 631-643.

Brehm, J. W., 1956. Postdecision changes in the desirability of alternatives. The Journal of Abnormal and Social Psychology $52(3), 384-389$.

Brockington, D., 2007. Forests, community conservation, and local government performance: The village forest reserves of Tanzania. Society \& Natural Resources 20 (9), 835-848.

Buchy, M., Hoverman, S., 2000. Understanding public participation in forest planning: a review. Forest Policy and Economics 1 (1), 15-25.

Cardenas, J.-C., 2004. Norms from outside and from inside: an experimental analysis on the governance of local ecosystems. Forest Policy and Economics 6 (3-4), 229-241.

Carmon, Z., Ariely, D., 2000. Focusing on the Forgone: How Value Can Appear So Different to Buyers and Sellers. Journal of Consumer Research 27 (3), 360-370.

CDC, 2007. Creating a Sense of Ownership. In: Forging Partnerships to Eliminate Tuberculosis: A Guide and Toolkit. Centers for Disease Control and Prevention (CDC), Atlanta.

URL http://cdc.gov/tb/publications/guidestoolkits/forge

Chambers, R., 1994. The origins and practice of participatory rural appraisal. World Development 22 (7), 953-969.

Chatterley, C., Linden, K. G., Javernick-Will, A., 2013. Identifying pathways to continued maintenance of school sanitation in Belize. Journal of Water, Sanitation and Hygiene for Development 3 (3), 411.

Cohen, J. M., Uphoff, N. T., 1980. Participation's place in rural development: Seeking clarity through specificity. World Development 8 (3), 213-235.

Conley, A., Moote, M. A., 2003. Evaluating Collaborative Natural Resource Management. Society \& Natural Resources 16 (5), 371-386.

Cooke, B., Kothari, U., 2001. Participation: the new tyranny? Zed books, New York.

Cornwall, A., 2008. Unpacking 'Participation': models, meanings and practices. Community Development Journal 43 (3), 269-283.

Cornwall, A., Brock, K., 2005. What do buzzwords do for development policy? a critical look at 'participation', 'empowerment' and 'poverty reduction'. Third World Quarterly 26 (7), 1043-1060.

Dal Bó, P., Foster, A., Putterman, L., 2010. Institutions and Behavior: Experimental Evidence on the Effects of Democracy. American Economic Review 100 (5), 2205-2229.

Davidson, R., MacKinnon, J. G., jan 2000. Bootstrap tests: how many bootstraps? Econometric Reviews 19 (1), 55-68.

Dietz, T., Ostrom, E., Stern, P. C., 2003. The struggle to govern the commons. Science 302 (5652), 1907-12.

Efron, B., Tibshirani, R. J., 1993. An Introduction to the Bootstrap. Chapman \& Hall, New York.

Etzioni, A., 1991. The socio-economics of property. Journal of Social Behavior and Personality 6 (6), 465-468.

FAO, 2011. State of the world's forests. The Food and Agriculture Organization (FAO), Rome.

Festinger, L., 1957. A Theory of Cognitive Dissonance. Stanford University Press, Stanford.

Freeman, R. E., 1984. Strategic management: A stakeholder approach. Cambridge University Press, Cambridge.

Gawronski, B., Bodenhausen, G. V., Becker, A. P., 2007. I like it, because I like myself: Associative self-anchoring and post-decisional change of implicit evaluations. Journal of Experimental Social Psychology 43 (2), 221-232.

Green, K. E., Lund, J. F., 2015. The politics of expertise in participatory forestry: a case from Tanzania. Forest Policy and Economics 60, 27-34. 
Greenwald, A. G., Farnham, S. D., 2000. Using the Implicit Association Test to measure self-esteem and self-concept. Journal of Personality and Social Psychology 79 (6), 1022-1038.

Handberg, Ø. N., Angelsen, A., 2015. Experimental tests of tropical forest conservation measures. Journal of Economic Behavior \& Organization 118, 346-359.

Harrison, G. W., List, J. A., 2004. Field experiments. Journal of Economic Literature 42 (4), 1009-1055.

Harrison, G. W., List, J. A., Towe, C., 2007. Naturally occurring preferences and exogenous laboratory experiments: A case study of risk aversion. Econometrica 75 (2), 433-458.

Henrich, J., Boyd, R., Bowles, S., Camerer, C., Fehr, E., Gintis, H., McElreath, R., 2001. In Search of Homo Economicus: Behavioral Experiments in 15 Small-Scale Societies. American Economic Review $91(2), 73-78$.

Hickey, G., Kipping, C., 1998. Exploring the concept of user involvement in mental health through a participation continuum. Journal of clinical nursing 7, 83-88.

Hoorens, V., Nuttin, J. M., Herman, I. E., Pavakanun, U., 1990. Mastery pleasure versus mere ownership: A quasi-experimental cross-cultural and cross-alphabetical test of the name letter effect. European Journal of Social Psychology 20 (3), 181-205.

Horowitz, J. K., Mcconnell, K. E., 2002. A Review of WTA / WTP Studies. Journal of Environmental Economics and Management 44 (3), 426-447.

Huber, J., Payne, J. W., Puto, C., 1982. Adding Asymmetrically Dominated Alternatives: Violations of Regularity and the Similarity Hypothesis. Journal of Consumer Research 9 (1), 90.

Huck, S., Kirchsteiger, G., Oechssler, J., 2005. Learning to like what you have - Explaining the endowment effect. The economic Journal 115 (505), 689-702.

Innes, J. E., 1996. Planning through consensus building. A new view of the comprehensive Planning Ideal. Journal of American Planning Association 62 (4), 460-472.

Johansson, P., Hall, L., Sikström, S., Olsson, A., 2005. Failure to detect mismatches between intention and outcome in a simple decision task. Science 310 (5745), 116-9.

Johnson, E. J., Häubl, G., Keinan, A., 2007. Aspects of endowment: A query theory of value construction. Journal of Experimental Psychology: Learning, Memory, and Cognition 33 (3), 461-474.

Kahneman, D., Knetsch, J. L., Thaler, R. H., 1991. Anomalies: The Endowment Effect, Loss Aversion, and Status Quo Bias. Journal of Economic Perspectives 5 (1), 193-206.

Kahneman, D., Tversky, A., 1979. Prospect Theory: An Analysis of Decision under Risk. Econometrica 47 (2), 263-292.

Knox, R. E., Inkster, J. A., 1968. Postdecision dissonance at post time. Journal of Personality and Social Psychology 8 (4), 319-323.

Koole, S. L., Dijksterhuis, A., van Knippenberg, A., 2001. What's in a name: implicit self-esteem and the automatic self. Journal of personality and social psychology 80 (4), 669-85.

Krugman, H. E., 1966. American Association for Public Opinion Research. The Public Opinion Quarterly 30 (4), 583-596.

Kőszegi, B., Rabin, M., 2006. A Model of Reference-Dependent Preferences. The Quarterly Journal of Economics 121 (4), 1133-1165.

Lachapelle, P., 2008. A Sense of Ownership in Community Development: Understanding the Potential for Participation in Community Planning Efforts. Community Development 39 (2), 52-59.

Lawrence, A., 2006. 'No Personal Motive?' Volunteers, Biodiversity, and the False Dichotomies of Participation. Ethics, Place \& Environment 9 (3), 279-298.

Lie, J. H. S., 2015. Developmentality: indirect governance in the World Bank-Uganda partnership. Third World Quarterly 36 (4), 723-740.

Lund, J. F., Saito-Jensen, M., 2013. Revisiting the Issue of Elite Capture of Participatory Initiatives. World Development 46, 104-112.

Lund, J. F., Treue, T., 2008. Are We Getting There? Evidence of Decentralized Forest Management from the Tanzanian Miombo Woodlands. World Development 36 (12), 2780-2800.

Maddux, W. W., Yang, H., Falk, C., Adam, H., Adair, W., Endo, Y., Carmon, Z., Heine, S. J., 2010. For whom is parting with possessions more painful? Cultural differences in the endowment effect. Psychological Science 21 (12), 1910-1917.

Manning, R., Ginger, C., 2007. An Owner's Manual to "Ownership": A Reply to Lachapelle and McCool. Society \& Natural Resources 20 (2), 187-192.

Mansuri, G., Rao, V., 2013a. Can participation be induced? Some evidence from developing countries. Critical Review of International Social and Political Philosophy 16 (2), 284-304.

Mansuri, G., Rao, V., 2013b. Localizing Development: Does Participation Work? World Bank, Washington D.C. 
Marks, S. J., Davis, J., 2012. Does User Participation Lead to Sense of Ownership for Rural Water Systems? Evidence from Kenya. World Development 40 (8), 1569-1576.

Markussen, T., Putterman, L., Tyran, J.-R., 2013. Self-Organization for Collective Action: An Experimental Study of Voting on Sanction Regimes. The Review of Economic Studies 81 (1), 301-324.

Moffatt, P. G., 2016. Experimetrics: Econometrics for Experimental Economics. Palgrave Macmillan, London.

Morewedge, C. K., Giblin, C. E., 2015. Explanations of the endowment effect: an integrative review. Trends in Cognitive Sciences 19 (6), 339-348.

Morewedge, C. K., Shu, L. L., Gilbert, D. T., Wilson, T. D., 2009. Bad riddance or good rubbish? Ownership and not loss aversion causes the endowment effect. Journal of Experimental Social Psychology 45 (4), 947-951.

Mwakalobo, A. B. S., Kajembe, G. C., Silayo, D. S., Nzunda, E., Zahabu, E., Maliondo, S., Kimaro, D. N., 2011. REDD and sustainable development - perspective from Tanzania. International Institute for Environment and Development (IIED), London.

Norman, M., Nakhooda, S., 2014. The State of REDD+ Finance. CGD Working Paper (378). URL www.cgdev.org/publication/state-redd-finance-working-paper-378

North, D. C., 1990. Institutions, institutional change, and economic performance. Cambridge University Press, Cambridge.

Norton, M. I., Mochon, D., Ariely, D., 2012. The IKEA effect: When labor leads to love. Journal of Consumer Psychology 22 (3), 453-460.

Nuttin, J. M., 1987. Affective consequences of mere ownership: The name letter effect in twelve European languages. European Journal of Social Psychology 17 (4), 381-402.

Ostrom, E., 1990. Governing the Commons: The Evolution of Institutions for Collective Action. Cambridge University Press, Cambridge.

Ostrom, E., Gardner, R., Walker, J. M., 1994. Rules, games, and common-pool resources. University of Michigan Press, Ann Arbor.

Pierce, J. L., Kostova, T., Dirks, K. T., 2001. Toward a Theory of Psychological Ownership in Organizations. The Academy of Management Review 26 (2), 298-310.

Plott, C. R., Zeiler, K., 2007. Exchange asymmetries incorrectly interpreted as evidence of endowment effect theory and prospect theory? American Economic Review 97 (4), 1449-1466.

Pretty, J. N., 1995. Participatory learning for sustainable agriculture. World Development 23 (8), 1247-1263.

Reed, M. S., 2008. Stakeholder participation for environmental management: A literature review. Biological Conservation 141 (10), 2417-2431.

Ribot, J. C., 2008. Building Local Democracy through Natural Resource Interventions An Environmentalist's Responsibility.

Ribot, J. C., Lund, J. F., Treue, T., 2010. Democratic decentralization in sub-Saharan Africa: its contribution to forest management, livelihoods, and enfranchisement. Environmental Conservation 37 (01), 35-44.

Richards, C., Blackstock, K., Carter, C., 2004. Practical Approaches to Participation. In: SERG Policy Brief. No. 1. The Macaulay Institute, Aberdeen.

Rodrik, D., 2000. Institutions for High-Quality Growth: What They Are and How to Acquire Them. Studies in Comparative International Development 35 (3), 3-31.

Scheba, A., Mustalahti, I., 2015. Rethinking 'expert' knowledge in community forest management in Tanzania. Forest Policy and Economics 60, 7-18.

Schultz, L., Duit, A., Folke, C., 2011. Participation, Adaptive Co-management, and Management Performance in the World Network of Biosphere Reserves. World Development 39 (4), 662-671.

Sen, A. K., 1999. Development as Freedom. Oxford University Press, New York.

Sills, E. O., Atmadja, S. S., de Sassi, C., Duchelle, A. E., Kweka, D. L., Resosudarmo, I. A. P., Sunderlin, W. D. (Eds.), 2014. REDD+ on the ground: The need for scientific evidence. CIFOR, Bogor.

Stern, N., 2006. Stern Review: The economics of climate change. Cambridge University Press, Cambridge.

Stieger, S., Voracek, M., Formann, A. K., 2012. How to administer the Initial Preference Task. European Journal of Personality 26 (1), 63-78.

Sutter, M., Haigner, S., Kocher, M. G., 2010. Choosing the Carrot or the Stick? Endogenous Institutional Choice in Social Dilemma Situations. Review of Economic Studies 77 (4), 1540-1566.

Symons, C. S., Johnson, B. T., 1997. The self-reference effect in memory: a meta-analysis. Psychological bulletin 121 (3), 371-394.

Thaler, R., 1980. Toward a positive theory of consumer choice. Journal of Economic Behavior \& Orga- 
nization 1 (1), 39-60.

TNRF, 2009. Using the nation's resources to reduce poverty? Tanzania Natural Resource Forum (TNRF), Arusha.

Treue, T., Ngaga, Y., Meilby, H., Lund, J., Kajembe, G., Iddi, S., Blomley, T., Theilade, I., Chamshama, S., Skeie, K., Njana, M., Ngowi, S., Isango, J., Burgess, N., 2014. Does participatory forest management promote sustainable forest utilisation in Tanzania? International Forestry Review 16 (1), 23-38.

Tyran, J.-R., Feld, L. P., 2006. Achieving compliance when legal sanctions are non-deterrent. Scandinavian Journal of Economics 108 (1), 135-156.

UN-REDD Programme, 2008. Framweork Document. FAO, UNDP, UNEP, Geneva.

UN-REDD Programme, 2011. The UN-REDD Programme Strategy 2011-2015. FAO, UNDP, UNEP, Geneva.

URT, 2012. National strategy for reduced emissions from deforestation and forest degradation (REDD + ). Vice president's office, United Republic of Tanzania (URT), Dar es Salaam.

Voors, M., Turley, T., Kontoleon, A., Bulte, E., List, J. A., 2012. Exploring whether behavior in context-free experiments is predictive of behavior in the field: Evidence from lab and field experiments in rural Sierra Leone. Economics Letters 114 (3), 308-311.

Weaver, R., Frederick, S., 2012. A Reference Price Theory of the Endowment Effect. Journal of Marketing Research 49 (5), 696-707.

Weiss, L., Johar, G. V., 2013. Egocentric Categorization and Product Judgment: Seeing Your Traits in What You Own (and Their Opposite in What You Don't). Journal of Consumer Research 40 (1), $1543-1559$.

World Bank, 2008. Putting Tanzania's hidden economy to work: Reform, management, and protection of its natural resource sector. World Bank, Washington D.C.

World Bank, 2015. Participation at Project, Program \& Policy Level.

URL http: //go.worldbank .org/ZBXXFC1QNO

\section{Appendix I: Descriptive statistics}

Table AI.1. Descriptive statistics at village level

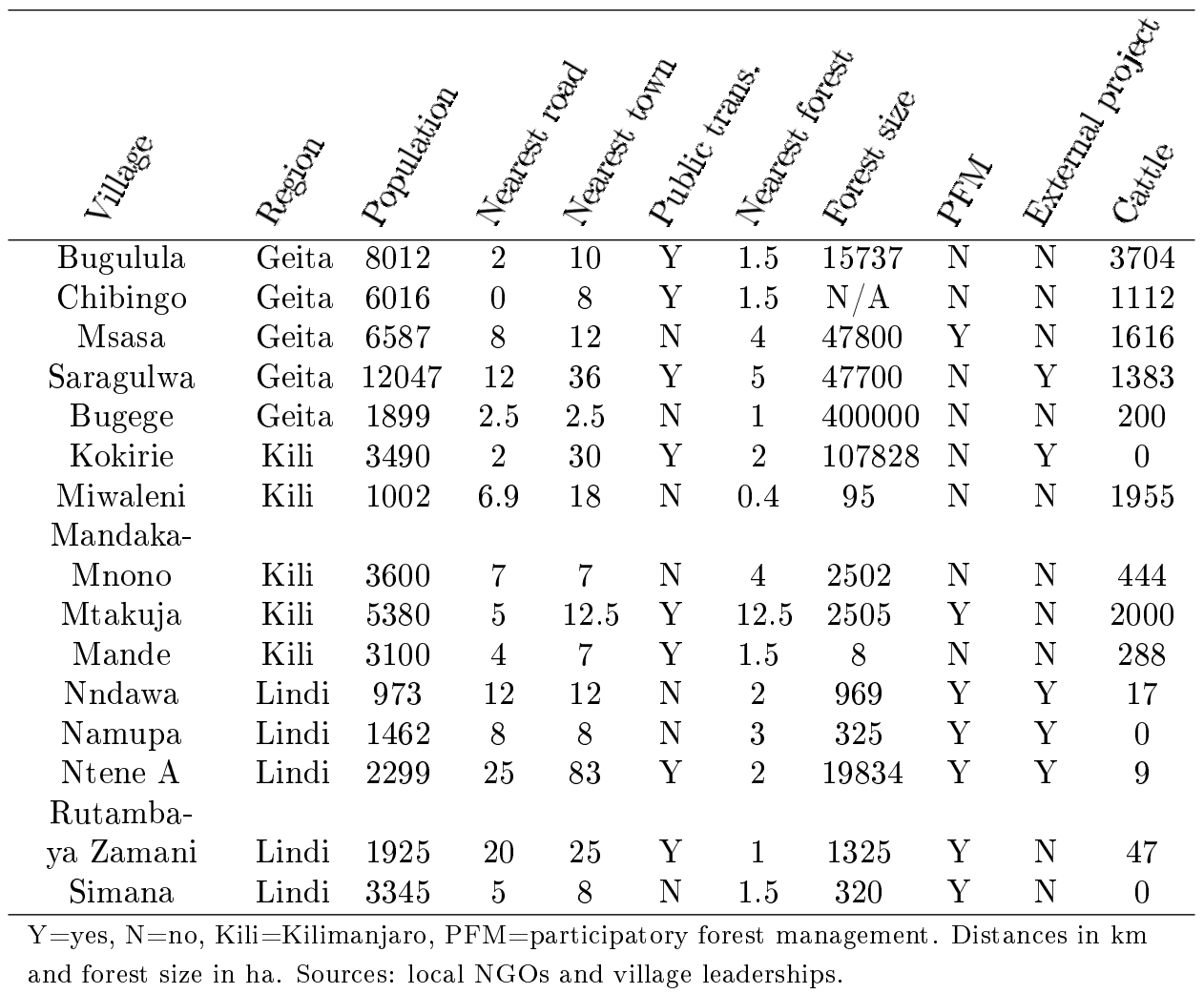


Table AI.2. Descriptive statistics at the individual level, by treatment group

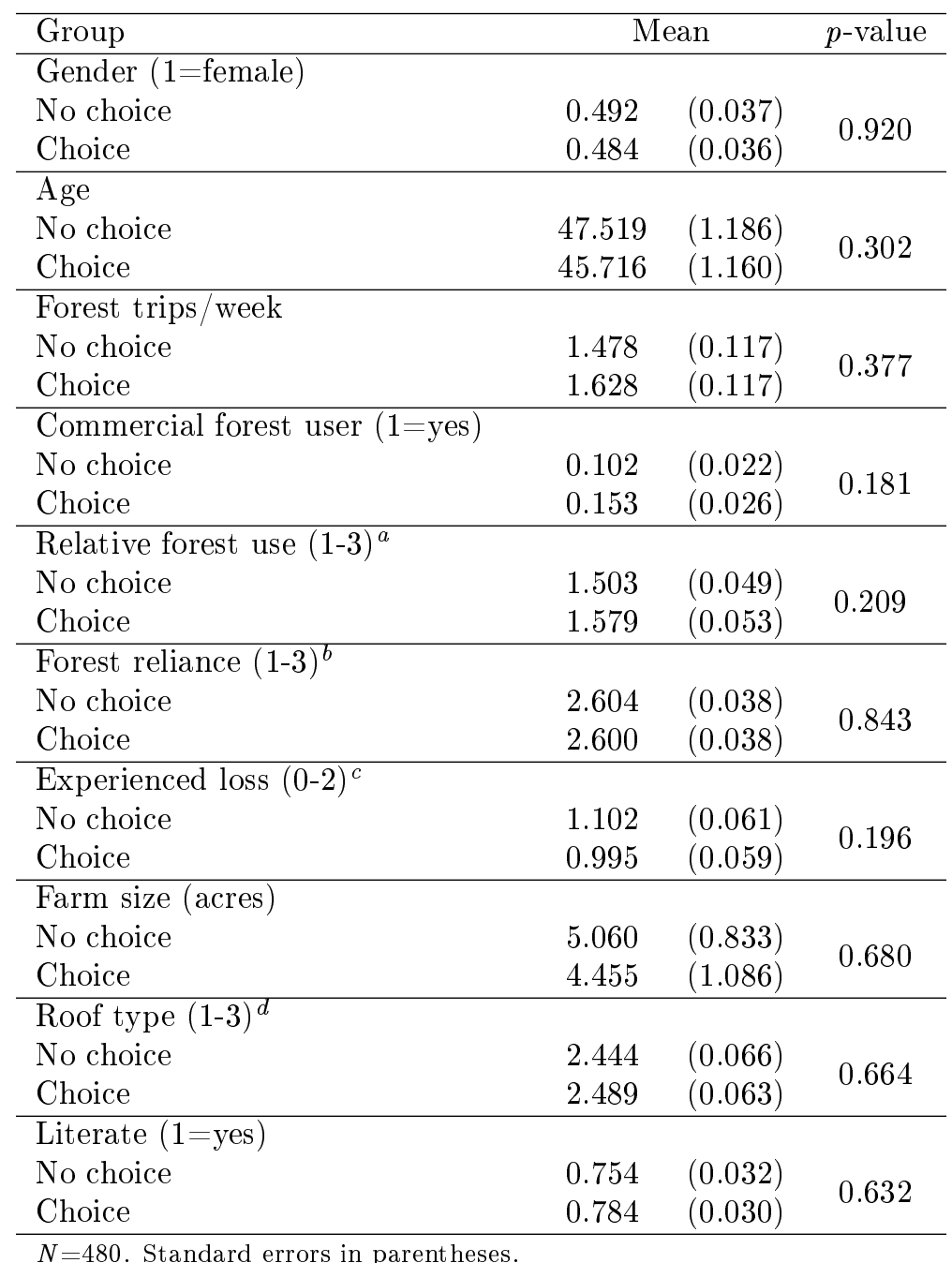

\footnotetext{
a The participant states to use less (1), about the same (2) or more (3) forest products than other households in the village.

${ }^{b}$ The participants regards the forest to be non-important (1), important (2) or essential (3) for the household.

$c$ The participants has experienced no (0), manageable (1) or severe (2) income shortfall/unexpectedly large expenditure in the past 12 months.

$d$ Most of the participant's roof consists of thatch (1), wood (2) or tin (3).
}

\section{Appendix II: Letter evaluations}


Table AII.1 presents the mean ratings of each letter, the number of participants who were presented with the given letter and how |many The fractions of participants who had the letter as their first letter vary. In particular, 44 of the 47 who where asked about the letter $A$ had the letter as the first letter in their stated name. The reason is that in addition to the first letter in their stated name, participants were asked about a letter not present in their stated names, and the letter $A$ is a common letter in Tanzanian names. Three letters - $Q, U, V$ - were not presented to any participant as no one had any as their first letter, leaving no basis for comparison.

Table AII.1. Overview of letter evaluations

\begin{tabular}{ccccc}
\hline Letter & \multicolumn{2}{c}{ Mean rating } & $N$ & $N$ as first letter \\
\hline A & 4.340 & $(0.167)$ & 47 & 44 \\
B & 4.047 & $(0.143)$ & 64 & 24 \\
C & 3.641 & $(0.228)$ & 39 & 15 \\
D & 3.969 & $(0.171)$ & 32 & 11 \\
E & 3.633 & $(0.052)$ & 480 & 29 \\
F & 3.725 & $(0.174)$ & 69 & 25 \\
G & 3.870 & $(0.167)$ & 54 & 13 \\
H & 4.060 & $(0.152)$ & 67 & 35 \\
I & 4.667 & $(0.167)$ & 9 & 6 \\
J & 3.773 & $(0.148)$ & 75 & 31 \\
K & 4.083 & $(0.140)$ & 36 & 13 \\
L & 3.860 & $(0.201)$ & 43 & 21 \\
M & 4.070 & $(0.115)$ & 114 & 61 \\
N & 3.889 & $(0.229)$ & 27 & 9 \\
O & 3.333 & $(0.374)$ & 15 & 4 \\
P & 3.940 & $(0.158)$ & 50 & 16 \\
R & 3.579 & $(0.054)$ & 480 & 29 \\
S & 4.010 & $(0.121)$ & 103 & 56 \\
T & 3.829 & $(0.223)$ & 35 & 12 \\
V & 3.675 & $(0.228)$ & 40 & 11 \\
W & 3.571 & $(0.571)$ & 7 & 2 \\
Y & 3.818 & $(0.377)$ & 11 & 5 \\
Z & 4.455 & $(0.157)$ & 22 & 8 \\
\hline Standard errors in parentheses. &
\end{tabular}

\section{Appendix III: Including nay-sayers}

Table AIII.1 reveals that participants who voted for the other payment scheme (nay-sayers, $N=17$ ) have a higher individual mean harvest rates than participants who voted for the PES scheme (yea-sayers, $N=175$ ) (bootstrapped $t$-test with 9999 repetitions and standard errors clustered at the session level). This could be because of spiteful behavior arising from losing the referendum, or because of unobservables that determine both voting and harvesting behaviors. Attempts to predict the probability to vote for the PES scheme by observables from the questionnaire produce no significant determinants.

Table AIII.1. Difference in mean harvest rate by vote

\begin{tabular}{|c|c|c|c|}
\hline Vote & Mean & larvest rate & $p$-value \\
\hline Nay & 0.450 & $(0.073)$ & \multirow{2}{*}{0.050} \\
\hline Yea & 0.291 & $(0.031)$ & \\
\hline
\end{tabular}

The following tables report the tests performed in Tables 3-4 and 6-8 with all participants. Including the nay-sayers in the tests does not change the findings. 
Table AIII.2. Mean individual harvest rates

\begin{tabular}{cccc}
\hline Group & Mean & & $N$ \\
\hline Control & 0.570 & $(0.060)$ & 96 \\
No- choice & 0.328 & $(0.044)$ & 192 \\
Choice & 0.305 & $(0.032)$ & 192 \\
\hline
\end{tabular}

Table AIII.3. Participants' PES evaluation by the choice treatment

\begin{tabular}{cccc}
\hline Statement & No choice & Choice & $p$-values \\
\hline Normative evaluation & $2.333(0.110)$ & $2.224(0.106)$ & 0.479 \\
Factual evaluation & $3.526(0.082)$ & $3.599(0.071)$ & 0.893 \\
PES and crowding-out & $3.453(0.072)$ & $3.391(0.077)$ & 0.616 \\
\hline$N$ & 192 & 192 & \\
\hline
\end{tabular}

Standard errors in parentheses. $p$-values produced by Wilcoxon ranksum tests.

Table AIII.4. Testing for associative self-anchoring

\begin{tabular}{cllll}
\hline & \multicolumn{2}{l}{ (1) Absolute positive } & \multicolumn{2}{l}{ (2) Relative positive } \\
\hline Choice & -0.072 & $(0.092)$ & -0.069 & $(0.069)$ \\
Positive & -0.088 & $(0.075)$ & -0.084 & $(0.049)$ \\
Choice* positive & 0.056 & $(0.076)$ & 0.084 & $(0.059)$ \\
Constant & $0.342^{* * *}$ & $(0.057)$ & $0.321^{* * *}$ & $(0.032)$ \\
\hline$R^{2}$ & \multicolumn{3}{c}{0.087} & \multicolumn{2}{c}{0.091} \\
$N$ & \multicolumn{2}{c}{384} & \multicolumn{2}{c}{384} \\
\hline
\end{tabular}

Dependent variable: individual mean harvest rate through the session. Session clustered standard errors in parentheses. $* * *, * *, *$ : significant at the 1,5 or $10 \%$ level. Includes village dummies (not reported).

Table AIII.5. Mean individual harvest rates

\begin{tabular}{|c|c|c|c|}
\hline Group & $20 \%$ & $60 \%$ & $100 \%$ \\
\hline No-choice & $(0.057)$ & $0.337 \quad(0.059)$ & $(0.028)$ \\
\hline Choice & $(0.051)$ & $(0.017)$ & $(0.032)$ \\
\hline$p$-values & 0.306 & 0.726 & 0.430 \\
\hline$N$ & 128 & 128 & 128 \\
\hline
\end{tabular}

Session clustered standard errors in parentheses. ***,**,*:

significant at the 1,5 or $10 \%$ level.

Table AIII.6. Regressing choice level harvest rate on treatments and controls

\begin{tabular}{cll}
\hline Variable & \multicolumn{2}{c}{ Harvest rate } \\
\hline Choice & -0.037 & $(0.032)$ \\
$60 \%$ (relative to $20 \%)$ & $-0.082^{* *}$ & $(0.034)$ \\
$100 \%$ (relative to $20 \%)$ & $-0.129^{* * *}$ & $(0.040)$ \\
Choice*60\% (relative to $20 \%^{*}$ choice) & 0.046 & $(0.038)$ \\
${\text { Choice* } 100 \% \text { (relative to } 20 \% \%^{*} \text { choice) }}^{*}$ & 0.027 & $(0.035)$ \\
$x_{i, t-1}$ & $0.638^{* * *}$ & $(0.034)$ \\
$\frac{\sum x_{j \neq i, t-1}}{7}$ & 0.027 & $(0.072)$ \\
Constant & $0.134^{* *}$ & $(0.048)$ \\
\hline$R^{2}$ & 0.468 & \\
$N$ & 2808 & \\
\hline
\end{tabular}

Session clustered standard errors in parentheses. $* * *, * * *$ : significant at the 1, 5 or $10 \%$ level. Includes village round dummies (not reported). 


\section{Appendix IV: Experiment materials in English}

\section{Instructions}

Thank you everyone for accepting this invitation. We will spend almost three hours explaining the activity, playing and conducting a short survey at the end. Let's start!

The following exercise is a different and entertaining way to actively participate in a project about forests. Besides participating in this exercise and earning money, you will answer a few questions afterwards. The funds to cover the expenses have been donated by a scientific body. The reason why we use money and paper trees is to create situations as similar to your real life situations as possible

The situation is one where a group, you, must make decisions about the use of a forest. You have been selected and asked to participate in a random draw from a list of all families in this village. This is done to make sure that all have the same chance of participating.

This exercise is different than exercises in which other persons in this community or others may have played already. Therefore, comments you have heard from other persons do not necessarily apply to this exercise.

Please pay a lot of attention to the instructions. If you understand the instructions, you will be able to make better decisions in the exercise. Please, remain seated and do not speak with other participants. If you have a question, raise your hand and we will answer your question.

So to the experiment, let's pretend this group has a forest of initially these 80 trees [point to the paper trees]. For 9 rounds, equivalent to for example years or wood harvest seasons, each of you will enter the forest and decide how many trees to harvest. You will each earn $\mathbf{1 0 0}$ shillings for each tree you decide to harvest. Think of this as equivalent to firewood, charcoal, timber etc. You can harvest a minimum of 0 trees from the forest and a maximum given by this table [Show the maximum harvest table]. You indicate how many trees you harvest by picking them [Show how trees are harvested]. The trees will be put up temporarily after you have harvested, such that each of you faces the same forest size.

After all of you have privately and anonymously harvested trees in one round, you are all gathered here and the total number of removed trees in that round is announced.

Then the forest grows: for every 10 standing trees, 2 trees are added. [Show how trees are added]

[If in treatment group 1-3:]

You will get an additional payment of your choice. There will be a referendum to ensure that you get the payment you want. You will get 3 minutes to discuss together. Then you will vote in in private on which payment you want.

You can choose between:

- Sell half of your trees. The 40 trees are valued at 2000 shillings, meaning you will be earn 250 shillings before the exercise starts. The forest is then decreased to 40 trees. 
OR

- You will be paid for not harvested trees. Since another country also benefits from your forest they would like to contribute to forest conservation, and therefore offer you a forest conservation payment. In addition to earning what we have already said, you will get [20/60/ 100] shillings for each tree you decide not to harvest. Therefore, if you decide to harvest 2 trees and you could have harvested 5 trees you will earn 200 shillings for the harvested trees, as before. But in addition you will earn [60/180/300] shillings for the 3 trees you did not harvest.

[Leave the participants alone for 3 minutes. Then they indicate their choice in private. After the referendum is held:] you have chosen to introduce [chosen payment]. Why did you choose this payment and not the other? [Note reasons]

[If in treatment group 4-6:]

You will get an additional payment. Instead of selling trees you will get paid for not harvested trees. Since other countries also benefit from your forest they would like to contribute to forest conservation, and therefore offer you a forest conservation payment. In addition to earning what we have already said, you will get [20/60/100] shillings for each tree you decide not to harvest. Therefore, if you decide to harvest 2 trees and you could have harvested 5 trees you will earn 200 shillings for the harvested trees, as before. In addition you will earn [60/ 180/300] shillings for the 3 trees you did not harvest. You now get 3 minutes in private where you can discuss the exercise.

[If in control group (7):]

You now get 3 minutes in private where you can discuss the exercise.

An example [Show as you explain]: Suppose that each of you harvests 3 trees each. When all of you are gathered here we then see that 24 trees are removed, leaving 56 trees. You each earn 300 shillings from the 3 harvested trees.

\section{[If in group 1-3:]}

In addition, as you have decided: you will receive [40/ 120/200] shillings from the forest conservation project.

[If in group 4-6:]

In addition: you will receive [40/ 120/200] shillings from the forest conservation project.

Afterwards, the forest grows by 10 trees to 66. Round 1 of a total of 9 rounds is then completed. Remember that everything you do is anonymous, so nobody can find out how much you harvest. Any questions? [Answer all questions]

Let us try a practice round! This is just for learning so you will not earn anything from this round. [Complete a full round. Answer any further questions]

Ok, now we reset the forest to 80 trees, and start the real exercise. Anything you will earn from now on will be noted and paid to you in real money at the end of the exercise. 
The upper limit table presented to participants

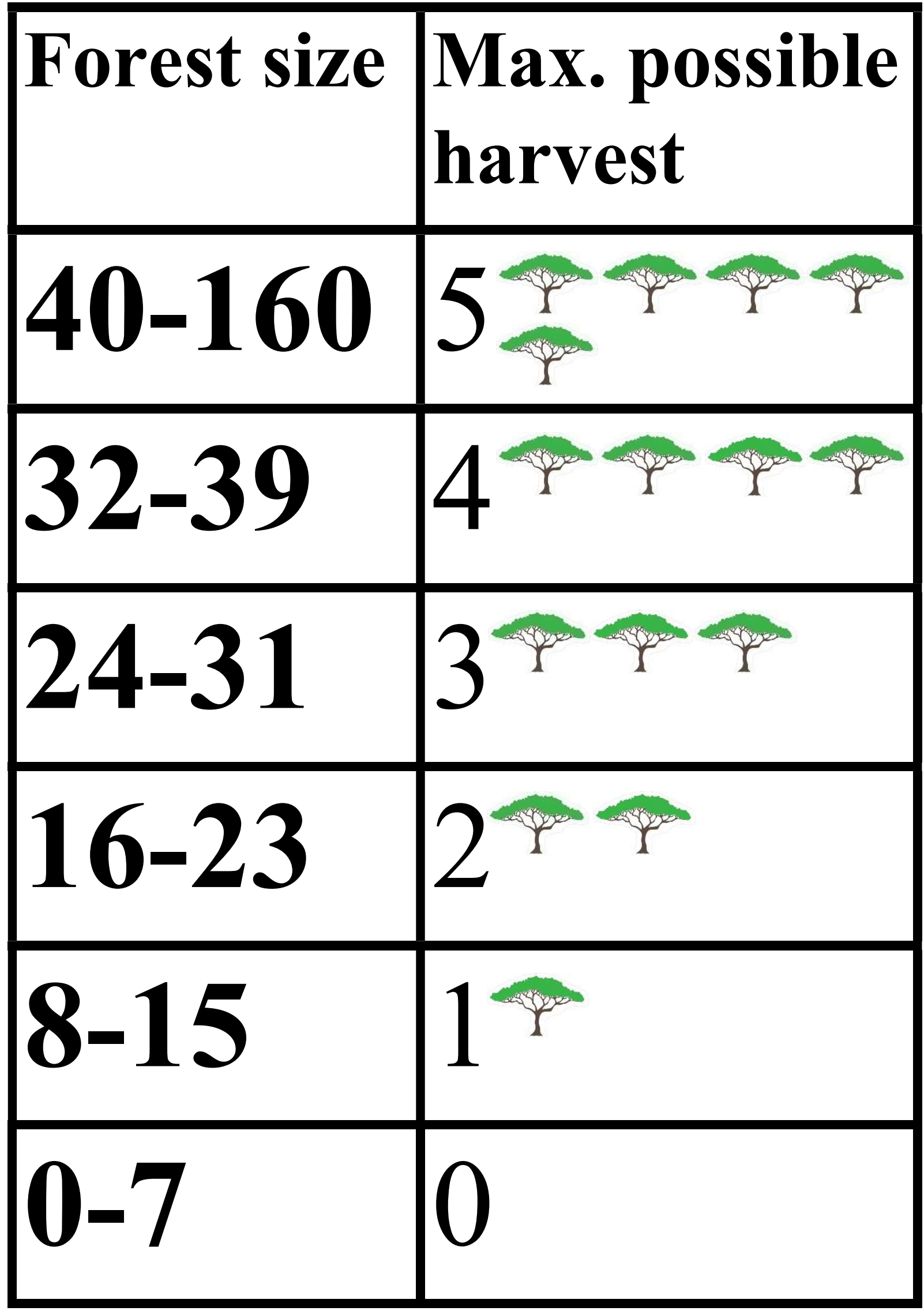


Participant questionnaire

\begin{tabular}{|c|c|c|}
\hline \multicolumn{3}{|c|}{ Basic information } \\
\hline \multicolumn{3}{|c|}{ Participant no. } \\
\hline \multicolumn{3}{|c|}{ Age } \\
\hline \multicolumn{3}{|c|}{ Gender $(1=$ female, $0=$ male $)$} \\
\hline \multicolumn{3}{|c|}{ About forest use } \\
\hline 1 & $\begin{array}{l}\text { How many times per week do you go to the forest to collect } \\
\text { forest products? (In the dry_season and the rainy season) }\end{array}$ & 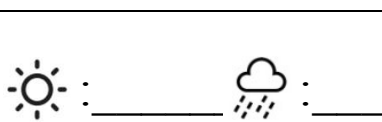 \\
\hline 2 & $\begin{array}{l}\text { Have you sold any forest products during the last month? } \\
(1=\text { yes, } 0=\text { no })\end{array}$ & \\
\hline 3 & $\begin{array}{l}\text { How much forest products do you use compared to other } \\
\text { families in the village? }(1=\text { less, } 2=\text { about the same, } 3=\text { more })\end{array}$ & \\
\hline 4 & $\begin{array}{l}\text { How important is the forest to you? } \\
(1=\text { not important, } 2=\text { important, } 3=\text { essential })\end{array}$ & \\
\hline 5 & $\begin{array}{l}\text { Do you consider the happiness of others in the village when } \\
\text { you harvest forest products? }(1=\text { yes, } 0=\text { no })\end{array}$ & \\
\hline \multicolumn{3}{|c|}{ About forest conservation and wealth } \\
\hline 7 & $\begin{array}{l}\text { If your religious leaders prohibit deforestation, would you } \\
\text { reduce your use of the forest? (yes }=1,0=\text { no) }\end{array}$ & \\
\hline 8 & $\begin{array}{l}\text { If payments for living trees are to be introduced, would you } \\
\text { prefer the payments to be made to the community or directly to } \\
\text { the individuals? ( } 1=\text { community, } 0=\text { individual })\end{array}$ & \\
\hline 9 & How many acres of land does your household own? & \\
\hline 10 & $\begin{array}{l}\text { How much livestock do you have? (number of cattle, goats, } \\
\text { donkeys, sheep) }\end{array}$ & $\mathrm{c:}$ \\
\hline 11 & $\begin{array}{l}\text { What type of material is (most of) your house's roof? } \\
\text { (1=thatch; } 2=\text { wood ; } 3=\text { tin; } 4=\text { tiles; } 9=\text { other, specify) }\end{array}$ & \\
\hline 12 & $\begin{array}{l}\text { Do you have any particular position in the village leadership? } \\
(1=\text { yes, } 0=\text { no) If yes, what? }\end{array}$ & \\
\hline 13 & $\begin{array}{l}\text { Has your household faced any major income shortfalls or } \\
\text { unexpectedly large expenditures during the past } 12 \text { months? } \\
\text { For example: death or serious illness in family, serious crop } \\
\text { failure, lost wage employment, land loss or any other loss? } \\
(0=\text { No, } 1=\text { yes but manageable, } 2=\text { yes severe })\end{array}$ & \\
\hline
\end{tabular}




\begin{tabular}{|c|c|c|}
\hline 14 & $\begin{array}{l}\text { Can you get help from others in the village if you are in need? } \\
\text { For example if you need extra money because someone in your } \\
\text { family is sick? }(0=\text { no, } 1=\text { sometimes, } 2=\text { yes })\end{array}$ & \\
\hline 15 & $\begin{array}{l}\text { Do you in general trust people in the village? }(0=\text { no, } \\
1=\text { sometimes, } 2=\text { yes })\end{array}$ & \\
\hline \multicolumn{2}{|r|}{$\begin{array}{l}\text { I will make some statements, please tell me to what degree } \\
\text { you agree to each claim }\end{array}$} & $\begin{array}{l}5=\text { Strongly agree } / 4=\text { agree } / \\
3=\text { ambivalent } / 2=\text { disagree } / \\
1=\text { strongly disagree }\end{array}$ \\
\hline 24 & $\begin{array}{l}\text { It is right that those who benefit from the clean air that our } \\
\text { forests produce contribute to conserving the forest. }\end{array}$ & \\
\hline 25 & $\begin{array}{l}\text { It is not proven that paying for living trees decreases } \\
\text { deforestation. }\end{array}$ & \\
\hline 26 & $\begin{array}{l}\text { Paying for living trees make other forest use considerations less } \\
\text { important; like tradition, culture and religion. }\end{array}$ & \\
\hline 27 & $\begin{array}{l}\text { The village council is doing the best possible actions to } \\
\text { improve the lives of its inhabitants. }\end{array}$ & \\
\hline \multicolumn{2}{|c|}{ About the experiment } & \\
\hline 28 & I felt like I owned the forest. & \\
\hline 29 & I felt like I owned the forest conservation project & \\
\hline 30 & $\begin{array}{l}\text { Did you participate together with any close friends or family in } \\
\text { the experiment? }(1=\text { yes, } 0=\text { no) If yes, how many? }\end{array}$ & \\
\hline 31 & $\begin{array}{l}\text { Did you have any particular harvest strategy in the experiment? } \\
\text { Why/why not? }\end{array}$ & \\
\hline 32 & $\begin{array}{l}\text { I am going to say four letters. Please indicate your first, } \\
\text { intuitive reaction to them: rate them by likeability ( } 5=\text { strongly } \\
\text { like, } 4=\text { like, } 3=\text { ambivalent, } 2=\text { dislike, } 1=\text { strongly dislike): }\end{array}$ & $\begin{array}{l}\mathrm{E}: \\
\overline{\text { (1 }} \\
\text { letter not in names })\end{array}$ \\
\hline 33 & Do you know how to read and write? $(1=$ yes, $0=$ no $)$ & \\
\hline
\end{tabular}




\section{Village level questionnaire}

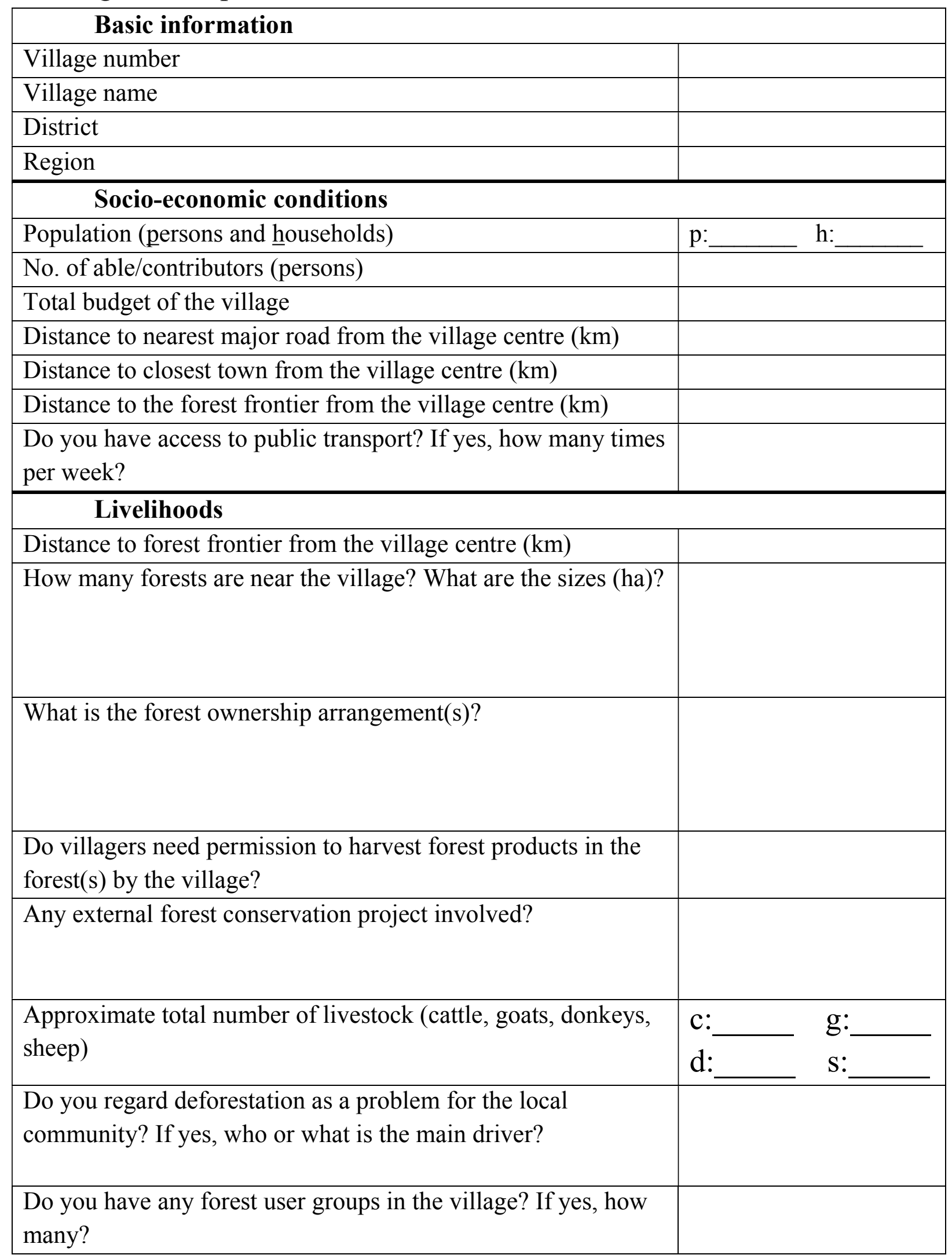

